\title{
FEATURES OF VALUE ORIENTATIONS OF STUDENTS OF FUTURE TEACHERS
}

Bakhtiyar Railevich Fakhrutdinov

Kazan Federal University, Kazan, Russia

Rezeda Kamilevna Khurmatullina

Kazan Federal University, Kazan, Russia

Nadezhda Petrovna Yachina

Kazan Federal University, Kazan, Russia

Flera Gabdulbarovna Mukhametzyanova

Kazan Federal University, Kazan, Russia

E-mail: fbakh93@mail.ru

Recepción: 05/08/2019 Aceptación: 16/09/2019 Publicación: 23/10/2019

\section{Gitación sugerida:}

Fakhrutdinov, B.R., Khurmatullina, R.K., Yachina, N.P. y Mukhametzyanova, F.G. (2019). Features of value orientations of students of future teachers. 3C TIC. Cuadernos de desarrollo aplicados a las TIC. Edición Especial, Octubre 2019, 232-245. doi: https://doi. org/10.17993/3ctic.2019.83-2.232-245

\section{Suggested citation:}

Fakhrutdinov, B.R., Khurmatullina, R.K., Yachina, N.P. \& Mukhametzyanova, F.G. (2019). Features of value orientations of students of future teachers. 3C TIC. Cuadernos de desarrollo aplicados a las TIC. Special Issue, October 2019, 232-245. doi: https://doi. org/10.17993/3ctic.2019.83-2.232-245 


\section{ABSTRACT}

The relevance of the study is due to the fact that life priorities, professional preferences of Russian youth have changed, new values have been formed. However, higher education is rarely conducted in accordance with the values and motivations of students. The aim of our study was to determine the structure and content of the values and motivations of student. The study of value orientations of students was conducted using the "polar" questionnaire, revealing the life, material, moral, aesthetic and professional values of students. B. S. Kruglov's method "Determination of formation of value orientations" was also used in our study. The study revealed the structure and content of values and motives of students - future teachers of one of the major universities. The results of the study are applicable for the pedagogical process of higher education.

\section{KEYWORDS}

Values, Motives, Learning Goals Of Students. 


\section{INTRODUCTION}

The transformations taking place in pedagogical education at present have actualized several important tasks that involve the improvement of the content and forms of professional training of teachers. The effectiveness of teacher education does not meet the modern needs of the school. The problem of value orientations and values of modern teachers is widely discussed in psychological and pedagogical science in connection with its relevance for the implementation of personality-oriented approach.

According to Botalova et al. (2016), the value orientation of future teachersresearchers such as "purpose", "means", "knowledge", "attitude", "quality" serve as internal regulators, guides the behavior of future teachers, determines the preference of aspirations and desires, and contribute to the transformation of norms and ideals, personal beliefs and life principle.

The influence of values and motivation on the development of students ' skills to formulate the problem based on critical thinking technology, on the formation of an inclusive competence of the future teacher is noted in a number of works (Akhmadullina et al., 2019).

According to Gurova (2000), and Dobrotvorskaya (2002), the idea that learning and its results is an important step on the path of life is the main value for students. The way to achieve life goals should be broken down into smaller sub-goals with a specific visible result. Then the transition to long-term planning will be painless.

Lidaka, Samusevica, and Striguna (2013) consider that it is very important that students discover the importance of different values in the educational process.

However, the structure and content of values and motivation of students - future teachers was not the subject of scientific analysis.

The aim of our study is to determine the structure and content of the values and motivations of students - future teachers. 


\section{METHODOLOGY}

The study of the content and structure of values and motivation of future teachers was conducted based on a number of theoretical and methodological approaches, including activity, personality-oriented, systemic and technological approaches. The following research methods were used: theoretical methods (analysis, synthesis and generalization of philosophical, cultural, artistic, pedagogical, psychological, methodical literature); empirical methods (questioning, observation, study of educational and creative works of students, interviews, conversations with students and teachers). B. S. Kruglov's method "Determination of formation of value orientations" was applied. The method of content analysis was used to study the motivation of students ' learning.

\section{RESULTS AND DISCUSSION}

The processes of transformation of value systems in modern society affect young people primarily because young people have a special susceptibility, insecurity and social mobility. At the same time, there is a dulling of value orientations among young people, especially among students. The system of value orientations reflects the attitude of students to the surrounding reality, an indicator of the stability of society, being also part of the spiritual sphere, a manifestation of social creativity. In this regard, the problem of study, formation of values of students of pedagogical high school in a reformed society, their structure and content are relevant. However, the understanding of content of values is different.

Values are defined as conscious representations of the subject of value to him, which are revealed by any verbal methods, both sociological and psychological (Leontiev, 1992).

Rokich (2002) defines values as “....abstract ideas, positive or negative, unrelated to a particular object or situation, expressing human beliefs about behaviors and preferred goals" as ...the firm belief that some purpose of individual existence, 
some mode of action is preferable from a personal and social point of view in all situations" (Slotina, 2008). The organization of educational activity is one of the ways of formation of motivation.

Any profession develops its own system of value orientations, professional ethics. Professional values are those personal factors based on which a person makes a choice in favor of certain decisions in the professional field, develops and performs own activities. Professional values provide the necessary motivation, personal socially significant result of all types of professional activity.

One of the ways of formation of motivation is the appropriate organization of educational activities. The content of the educational material is absorbed by students in the learning process. The result of training, development and education of the individual depends on the content of this activity, what parts (individual educational activities) it consists of, how these parts relate to each other, what is their content, what is the structure of educational activities. The success of educational activities also depends on what it is aimed at, what goals students achieve. According to Gabdreev and Smirnov (2008) «the attitude of students to their own activities is largely determined by how the teacher organizes their educational activities, what are its structure and the nature of the presentation of educational material».

Meanwhile, it should be noted that at present, science has not developed a unified approach to the problem of motivation of human behavior, terminology has not been established, and the basic concepts have not been clearly formulated. Markova (1983) defines motivation as "a set of psychological reasons that explain human behavior, its beginning, direction and activity".

Kamenskaya (2003) believes that the motives and values of a student are purchased, are formed during its ontogenetic development. The motive is the pursuit of some rather General target States, types of satisfaction or results. The way to effective learning is through understanding its motivation. Only knowing what motivates the student, what motivates him to work, what motives are the basis of his actions, you can try to develop an effective technology of motivation 
management training. To do this, you need to know how certain motives arise or are caused, how and by what methods the motives can be put into action. Thus, the decisive factor in the effectiveness of training is motivation.

Outstanding psychiatrist, neurologist and psychologist Myasishchev said that the results that a person achieves in his life depend on his intelligence only by 20$30 \%$, and $70-80 \%$ depends on the motives that encourage him to behave in a certain way (Lisovets, 2019).

Educational motivation is a private type of motivation included in educational activities. Educational motivation is determined by a set of factors: first, the educational system, educational institution; second, the organization of the educational process; third, and the subjective characteristics of the student; fourth, the specifics of the discipline.

At the same time, a significant relationship of intellectual development with the success of educational activities has not been proven. A pattern is revealed: "strong" students differ from each other, but not in terms of intelligence, but in strength, quality and type of motivation. Strong students are characterized by internal motivation - mastering the profession at a high level and focus on obtaining professional competencies, and for weak students - external motivation - avoiding condemnation and punishment for poor learning, so the activation of cognitive activity of the student without the development of his cognitive interest is not only difficult, but almost impossible. That is why the cognitive interest of students in the learning process should be systematically excited, developed and strengthened as an important motif of teaching, as a strong personality trait, as a powerful means of educating learning, improving its quality.

Educational activities associated with creativity. However, it is difficult to attract poorly motivated or even unmotivated students to creative activity, since the initial motivation of the student is of great and sometimes crucial importance for the stimulation of creative self-development. 
According to Andreev (2000), among the motives of this specific type of activity can be identified:

1) desire to enjoy recognition and respect in the group;

2) the desire to be strong, healthy, intellectually more developed;

3) the desire to achieve success in school, sports, in life, to take a worthy place in society;

4) the desire to make a career, have a prestigious profession, work;

5) the desire to earn well, to be financially secure;

6) the desire to overcome themselves, improve their abilities;

7) the desire to raise the level of requirements to yourself, get rid of bad habits, etc» (Andreev, 2000).

In addition to the lack of motives, several external and internal reasons can hinder the creative self-development of students:

1) inability to finish the work to the end;

2) lack of ideals;

3) lack of stimulation to the process of training by teachers;

4) lack of peer support;

5) lack of faith in yourself, in your own strength;

6) ignorance of yourself, your strong and weak qualities;

7) lack of literature on self-development;

8) lack of a friend (of a friend) with whom you can consult "the secret". 
The study of the structure of motivations of University students, knowledge of the motives that lead to a activity, allows psychologically sound to solve the problem of increasing the effectiveness of training, as the path to effective learning lies primarily through the understanding of its motivation. Thus, the main factor in improving the effectiveness of training is its motivation.

The study of the system of needs and motives of training students of one of the universities in Russia based on the above concept was conducted by us based on one of the universities in Russia.

Kruglov's method "Determination of formation of value orientations" was applied in the study. The following life goals were ranked on a five-point scale of importance:

1. Autonomy as independence in judgments and estimates:

2. Self-confidence (freedom from internal contradictions, doubts)

3. Material security (no material difficulties in life)

4. Health (physical and mental)

5. Fun (life full of pleasure, fun, enjoyable time)

6. Interesting work

7. Love (spiritual and physical intimacy with a loved one)

8. Freedom as independence in actions and actions

9. Beauty (the experience of the beautiful in nature and art)

10. Good and loyal friends

11. Knowledge (possible expansion of their education, Outlook, intellectual development)

12. Happy family life

13. Creativity (possibility of creative activity)

14. Public recognition (respect of others, collective, companions) 
15. Active, active life

16. Equality (brotherhood, equal opportunities for all).

This method was used to identify the content of the goals (values) of life of 1 st year students, future teachers.

The method of content analysis was used to identify the motives of students' learning. We asked students to write several motives for their studies at the University. However, then we chose only those motives of learning that were in the first place. Working with synonyms made it possible to identify seven main motivations for the training of students of the University. Next, we calculated how many percent of students put this or that motive of learning in the first place.

You can see from Table 1, both at the level of normative ideals (that is, at the level of beliefs) and at the level of individual priorities (that is, in specific actions), for students the most significant are the values of achievement (personal success in accordance with social standards), independence of thought and action, as well as the value of security (stability of society, relations and oneself).

Table 1. The ratio of values of different groups of students.

\begin{tabular}{|c|c|c|c|c|}
\hline \multirow{2}{*}{ Types of values } & \multicolumn{3}{|c|}{ Average index and rank the types of values } \\
\hline Conformity & Level of normative ideals & Level of individual priorities \\
\hline Traditions & 2,69 & 4 & 1,93 & 4 \\
\hline Kindness & 2,25 & 6 & 0,90 & 9 \\
\hline Universalism & 2,45 & 5 & 1,05 & 8 \\
\hline Independence & 1,84 & 9 & 0,74 & 10 \\
\hline Stimulation & 3,95 & 2 & 2,34 & 1 \\
\hline Hedonism & 1,90 & 8 & 1,83 & 5 \\
\hline Progress & 1,65 & 10 & 1,23 & 7 \\
\hline Authority & 4,72 & 1 & 2,13 & 3 \\
\hline Security & 2,05 & 7 & 1,61 & 6 \\
\hline
\end{tabular}

Values such as hedonism (enjoyment), universalism (understanding, tolerance, and protection of the well-being of all people and nature), and stimulation have the least significance at the level of normative ideals. Values such as universalism, tradition and kindness have the least significance at the level of individual 
priorities. Respect and maintenance of customs, acceptance and acceptance of ideas existing in a culture, understanding and tolerance do not take priority in the system of values of modern youth of this sample. Even though at the level of normative ideals these values occupy a priority place in the system of value orientations of students, they are implemented in specific actions and behavior is not always.

\section{SUMMARY}

The study based on the analysis of literary sources justified the need to rely on the psychological approach in teaching students.

The structure of values of students is revealed:

- the group of values in self-expression came to the first place, it is included in the zone of dissatisfaction;

- the group of material values was in second place, it also entered the zone of dissatisfaction;

- the group of values in recognition came in third place; it was in the zone of partial dissatisfaction.

Two groups of values have entered the zone of satisfaction: value in security and value in social relations. This structure of values of students led to the formation of a certain structure of motives of students ' learning.

The rating of motives of training of the surveyed students in high school is defined:

- getting an education in order to find your favorite job;

- obtaining a diploma that would allow you to find a high-paying job;

- education for a decent future;

- training for self-development;

- obtaining knowledge for development in the profession; 
- education with the aim of obtaining personal freedom;

- education as a common behavior.

Two unsatisfied values of students in self-expression and material values, acting in the consciousness of the student together, generate the corresponding motivation of learning and, accordingly, the goals that the student is already aware of. Two unsatisfied values lead to the first place mainly goals related to the material (financial) provision of University graduates in the future. Self-development, development in the profession as the motives of learning pushed to lower places in the ranking of motives. Some students do not realize why they are studying at all ("I am learning because everyone is learning").

\section{CONCLUSIONS}

Therefore, you must create the student's opportunities to meet the valueexpression, engaging them in active and creative scientific activity, and using active learning methods. It is important to stimulate the development of motivation for learning and creative personal self-development of each student in order to improve the efficiency of training students at the University.

It is motivation that is the main tool that will make it possible to increase the level of students ' interest in the educational process, will increase personal scientific creativity. The study of motivation and its formation are two sides of the same process of education of the motivational sphere of the integral personality of the student. The study of educational motivation is necessary to identify the real level and possible prospects, as well as the zone of its immediate impact on the development of each student. In this regard, the results of the study of the process of motivation of learning, showed new processes of the relationship of the content of the educational process and the formation of students ' new goals and needs. 


\section{ACKNOWLEDGEMENTS}

The work is performed according to the Russian Government Program of Competitive Growth of Kazan Federal University.

\section{REFERENCES}

Akhmadullina, R., Valiakhmetova, N., \& Khurmatullina, R. (2019). Students - future teachers development of abilities to formulate a problem on the basis of critical thinking technology. Proceedings of INTCESS 2019-6th International Conference on Education and Social Sciences, 4-6 February 2019- Dubai, U.A.E., 366-372.

Akhmadullina, R., Valiakhmetova, N., \& Khurmatullina, R. (2019). Video cases as a means of forming of motivational component of inclusive competence of students - future teachers. Proceedings of INTCESS 2019-6th International Conference on Education and Social Sciences, 4-6 February 2019-Dubai, U.A.E., 360-365.

Andreev, V. (2000). Pedagogy: Training Course for Creative Self-Development (2 ${ }^{\text {nd }}$ ed.). Kazan.

Botalova, O. B., Osipova, S. V., Asenova, N. S., Kenenbaeva, M. A., Kuderina, A. Y., Zholtaeva, G., ... \& Azanbekova, G. (2016). Value Orientations of Future Teachers-Researchers. International fournal of Environmental and Science Education, 11(17), 10279-10288.

Dobrotvorskaya, S. (2002). Orientation of students to healthy lifestyle through understanding of life goals and values. Pedagogical Education and Science, 1, 5155.

Gabdreev, R., \& Smirnov, A. (2008). Formation of motivation of educational and cognitive activity of University students. Education and self-Development, 10, 227-233. 
Gurova, R. (2000). The Spiritual world of youth in the changing Russia of the XX century (longitudinal sociological research of 1960-2000). The World of Psychology, 4, 147-158.

Kamenskaya, E. (2003). Fundamentals of Psychology. Rostov.

Leontiev, D. (1992). Method of Studying Value Orientations. Moscow.

Lidaka, A., Samusevica, A., \& Striguna, S. (2013). Values actualization in the educational process. 1st Annual International Interdisciplinary Conference, AIIC 2013, 24-26 April, Azores, Portugal - Proceedings, 968-976.

Lisovets, N. (2019). Professional motivation of students as a way to activate learning. Retrieved from http://festival.1 september.ru/articles/598947/

Markova, A. K. (1983). Formation of Learning Motivation in School Age. Moscow.

Slotina, T. (2008). Psychology of Personality: Textbook. St. Petersburg. 